\title{
Belief in God among South African youth
}

Johannes A van der Ven, Jaco S Dreyer \& Hendrik J Pieterse

Department of Practical Theology

University of South Africa

\begin{abstract}
This article investigates belief in God among 538 students from standard 9 who attend Anglican and Catholic schools in the Johannesburg/ Pretoria region. Within their belief in God they make use of different interpretations, namely anthropomorph theism and panentheism, nonanthropomorph theism and panentheism, as well as what is called aniconic transcendent pantheism. These interpretations do not appear to exclude one another, but co-exist in the students' minds.
\end{abstract}

\section{INTRODUCTION}

With few exceptions, international surveys show a decline of religiosity and church participation in western countries since the sixties. In some of these countries the decreasing belief in God and church engagement even show dramatic features, as is the case in the northern part of Western Europe, especially the Scandinavian countries, the Netherlands, Belgium, Germany and France. In the southern part, a religious and church decline can be perceived as well, but to a much lesser degree, partly because people have hardly adhered to the official creed of the church at all this century. Not only in Europe, but also in the United States and Canada, churches are becoming significantly emptier during weekend services and people are committing themselves less to them (Ester, Halman \& De Moor 1993). The question of what has caused this process of secularization is not easy to answer. One of the theories refers to the modernization process in society that rationalizes all of people's thinking, feeling, valuing and acting, and undermines the perspective of transcendence from which they used to live their lives before. This modernization process is supposed to have begun in the northern part of Western Europe, then influenced North America, and diffused from there all over the world. Although this theory is negatively identified as a sign of Eurocentrism and Americanization, the process itself is believed to be ongoing (for diffusion theory, see Doorenbos et al 1987). This applies even more so since the nineties because of the tearing down of the Berlin wall and the decline of communism that brought this about. What we call globalization today is for the most part global modernization (see for example Beyer 1994). 
The question that now arises is whether the process of secularization that is supposedly determined by the modernization process, will also affect South Africa or whether, in fact, it is already doing so. A crucial role will be played by South African youth, as young people's thinking, feeling, evaluating and behaving are always and everywhere a sign of the times to come. For this reason we pay attention to the South African youth's religiosity, especially their belief in God. In the first part we specify the problem that is implied in this belief in God. In the second and third parts we pay attention to two different empirical approaches to belief in God. In the second part we deal with a historical approach and in the third part with a systematic approach. We close this article with a conclusion.

\section{BELIEF IN GOD AS A PROBLEM}

Although the new constitution of 1996 makes South Africa secular state politically, socially it still is a deeply religious, that is Christian, society. The evidence for this statement comes from the 1991 census. About $95 \%$ of those who answered the question regarding the religious group they belong to, indicated that they were affiliated with a Christian community. Of these Christians, about $40 \%$ are committed to the mainline Protestant churches (Dutch Reformed church 18\%, Methodist church 9\%, Anglican church 6\%, Lutheran church 4\%, Presbyterian church $2 \%$ ), 34\% to the African Independent Churches, to which 4000 different churches belong, $11 \%$ to the Catholic church, $7 \%$ to the Zion Christian Churches and the rest to other Christian churches (Population Census 1991:150ff).

Another impressive sign of South Africa's religiosity can be deduced from what the first democratic state president, Nelson Mandela, has written about himself and his party, the African National Congress (ANC). Mandela's policy is based on the dignity of each and every human being and human rights, absolutely irrespective of gender, race, skin colour, or creed. He explicitly calls himself a Christian, namely a Methodist, having been baptized into the Wesleyan church, as he appreciated the sermons on Sunday morning on Robben Island, not only for reasons of relaxation, as some of his comrades there, but also for reasons of religious meditation and reflection (Mandela 1995:15, 313, 536). In a speech in Afrikaans to representatives of Afrikaner organizations he said that the ANC had always taken humanistic values as its principal guideline, as can been seen from its Freedom Charter, but also adhered to the basic Christian principle of all people created according the image of God (see Inleidende opmerkings deur president Nelson Mandela by 'n ontmoeting met Afrikaner meningsvormers, Pretoria, 28 Junie 1995, in Naudé 1995:185-188). 
But perhaps an even more impressive indication of South Africa's religious nature under the new constitutional order can be found in the membership of the Truth and Reconciliation Commission. The 'Promotion and Reconciliation Act' of July 1995, the goal of which is to establish the truth about gross violations of human rights between 1960 and 1995 and promote reconciliation in this deeply divided society, does not make any allusion to any religious frame of reference from which this Commission should operate. This is amazing, because the very aim of the Commission is stated in almost explicitly religious terms, or at least in terms which are easily and even spontaneously associated with the Gospel: 'there is a need for understanding but not for vengeance, a need for reparation but not for retaliation, a need for ubuntu but not for victimization'. Both the Chairperson and the Vice-Chairperson of the Commission stem from religious circles, namely the emeritus Anglican Archbishop Desmond Tutu and the Methodist theologian Dr Alex Boraine. This most important institution to operate in the new South Africa - the Act made the Commission a juristic person - officially strives to realize one of the main longings Desmond Tutu as a prophet loudly stated, expressed, and even cried for during the inhuman order of apartheid established in 1948: reconciliation, albeit not without establishing truth, confession, and reparation ${ }^{2}$. South Africa is a secular state, and this act is secular in nature, but socially it is deeply rooted in and influenced by religious, that is evangelical, aspirations and motivations. In other words, South Africa is a religious society. In order to empirically explore its religious nature, in this article we investigate the belief in God among a specific part of the South African youth, for example the students from standard 9 who attend Anglican and Catholic schools in the Johannesburg/Pretoria region ${ }^{3}$. We think investigating South African students from standard 9 is relevant, because they are the bearers of societal and cultural, especially religious developments to come. Moreover, investigating South African students from standard 9 who attend Anglican and Catholic schools is the more relevant, in that they day in day out participate in the religious curriculum of these schools in all its formal, informal and hidden aspects. Which students might be more religious than they are?

In order to investigate this belief itself, we do not restrict ourselves to a single item in the sense of 'Do you believe in God?', but we focus on different interpretations of God among South African youth and the extent to which they evaluate these interpretations in a positive or negative way. From all of this two specific questions can be formulated: 1) What interpretations of God exist among South Africa youth?, 2) How do they evaluate these interpretations? We try to answer these questions from a sample survey we conducted in 1995 among 538 students from standard 9 who attend Anglican and Catholic schools in the Johannesburg/Pretoria region. This sample approaches the empirical universum of standard 9 students in schools affiliated to both churches in the Johannesburg/Pretoria region. 


\section{A HISTORIC APPROACH TO BELIEF IN GOD: THE SOCON INSTRU- MENT}

As mentioned, we decided not to restrict ourselves to a single item in the sense of 'Do you believe in God?', as the European Value Systems Study Group (EVSSG) did in 1978 as well as the later European Values Study Group (EVS) in 1990 (Halman et al 1987:299, Ester et al 1993:283). Likewise, the International Social Survey Project seemed satisfied with only one question about belief in God, although in this case a time aspect was added, making it possible for the respondent to check the following answers: 'never believed, 'believed, but now don't', 'didn't but do now,' and 'always believed' (Greeley 1995:84-86, 97).

Regardless of how important this method is, the drawback of asking a single question is that the respondents are compelled to formulate their answers according to the pattern of that one question. Furthermore, different respondents may interpret this question in different ways. The statement 'I believe in God' can be understood in an authentic biblical way, a deistic way, or a fundamentalistic way (Van Peursen 1981). The only way to avoid this problem is by combining different items.

But the question arises of what different items to combine. The items one uses refer to or stem from a cognitive frame of reference from which the issue of belief in God is approached. And so the question is: what cognitive frame of reference is appropriate? Using only one item like 'Do you believe in God?' assumes this belief in God to be acognitive or precognitive in nature. We do not wish to go into a discussion here of whether and to what extent acognitive or precognitive beliefs really exist, espe cially in the prelinguistic stage of the child's development, because we are not dealing here with very small children who are not able to express themselves in a semantically and syntaxically appropriate manner. Our concern is standard 9 adolescents, who have already reached the Piagetian stage of formal-operational thinking 4 . So the cognitive frame of reference that underlies the belief in God poses a serious question.

As we said in the introduction, we used two different approaches in our research, namely a historical and a systematic one. In these approaches, two different measuring instruments are used that consist of two different lists of items. The first instrument stems from the Nijmegen sociological research program 'Sociale en Culturele Ontwikkelingen in Nederland' (SOCON) (in English 'Social and Cultural Developments in the Netherlands'), which was used for the first time in 1979, and after that in the panel research in 1985, 1990 and 1995. Here we call it the SOCON instrument (e.g. Felling, Peters \& Scheepers 1992). The second instrument has been developed over the last ten years by the 'Nijmeegs Instituut voor Studies in de Empirische Theologie' (in English the 'Nijmegen Institute of Studies in Empirical Theology') (NISET) that was 
incorporated in the SOCON panel research in 1995. Here we call it the NISET instrument (Sociaal-Culturele Ontwikkelingen in Nederland 1995). The reason for using both approaches and both instruments was that we appreciated the first instrument for its statistical reliability ${ }^{5}$, but questioned its conceptual and construct validity, as we will clarify further on. We added the second instrument because we believed it to be a valid operationalization on philosophical and theological grounds, but were unsure about its reliability. In this part we restrict ourselves to the SOCON instrument and in the next one we deal with the NISET instrument.

The SOCON instrument is based on three concepts, which are supposed to match consecutively with religious consciousness in the premodern and modern 'Zeitgeist', albeit without being connected with one another within an overarching theory (Van der Ven 1993). These three concepts may be seen as stemming from three different periods of time within western history, although the SOCON documents do not make any explicit allusion to them ${ }^{6}$. The first concept, called 'traditional Christian belief in God', stems from the Christian tradition, in so far as this tradition has been built on the religious plausibility structures of Christianity in premodern times ${ }^{7}$. The second concept, called 'deism', stems from modern times, which begin with the Enlightenment in the 18th century and continue into our own days (Gay 1966, 1968). The third concept, called 'immanentism', stems from what we might label the second wave of modern Enlightenment during the so-called cultural revolution in the sixties and seventies of this century, in which all religious verticalism, so to say, was reduced to horizontalism: God does not exist above the world, but within the world only, especially within the human relations of mutual care and love ${ }^{8}$.

The first concept, traditional Christian belief in God, refers to a personal God who takes care of everybody personally. The term 'personal' is used in two different ways here: it refers to God as a person and to each and every individual human person whom God loves. In the following item, which functions as the operationalization of this concept, the word Himself' refers to God as a person, whereas the word 'personally' refers to the individual human being: 'There is a God who occupies Himself with every human being personally'.

The second concept, deism, is supposed to fit into the cultural climate of Enlightenment, which still permeates today's modernity. In this concept, God is distanced from any anthropomorphic image or attribute and seen as a non-personal higher power that exists without intrinsically being connected to and engaged with any humans. The most exemplary item reads as follows: 'There is something beyond this world'. From empirical research we know that today many people value this deism in a rather positive way, sometimes in a more positive way than they value what is called the tradi- 
tional Christian belief in God ${ }^{9}$. Some scholars however evaluate this deism in rather or even outright negative terms for two reasons. The first is that deism does not fit into the main stream of biblical thought about God, in which God is seen as the divine creator and liberator of people and their world. The second reason is that deism leads to a non-anthropomorphic, abstract, bleak, vague and even a vanishing God, which results in all kinds of uncritical, even dangerous civil religion, because it legitimizes the society's status quo, whatever this status quo may be, from the narrowminded selfinterests of the conventional, capitalistic bourgeoisie to the God-forbidden evil of the Nazi state or the apartheid system ${ }^{10}$. The scholars who support the first argument are right, but this cannot prevent us from studying and researching this deism. In our opinion, those who support the second reason are too quick in their judgments, because non-anthropomorphism, abstractness, and vagueness are different concepts, not to mention that these concepts almost automatically lead to civil religion, a Nazi state, or an apartheid system. We believe that what is necessary is to study deism as carefully as possible in all its dimensions and aspects before judging and evaluating it.

In the third concept, immanentism, God is seen as being the very core of human existence. In itself, this concept might be considered to belong to the Christian tradition, because what is more a Christian insight than that God dwells in the hearts of humans, were it not that the SOCON sociologists understand this immanentism in a reductionistic way. In other words, immanentism means that God is reduced to being a function of human existence only. The two items by which this concept is measured read as follows: 'To me, God is nothing but the valuable in a human being' and 'God is not up there, but only in the hearts of people'.

As we have already said, the SOCON instrument, consisting of the said three concepts, frequently appeared to be a reliable instrument, but we doubt its conceptual and construct validity for several reasons.

The first reason relates to the factor labeled 'traditional Christian belief in God'. The question is why both items constituting this factor are called traditional, namely 'There is a God who occupies Himself with every human being personally' and 'There is a God who wants to be God for us'? These items do not belong exclusively to premodern times, as they are valid for all ages, which stretch into our own times, as today's modern religious verses, songs, and liturgical texts show ${ }^{11}$. A further question is why this factor in particular is called Christian, whereas both other factors are implicitly referred to as non-Christian. The SOCON instrument is presumably based on the assumption that Christian belief in God can only be a belief in a personal God, which is explicitly stated in both items mentioned, while this is missing in the items 
that belong to both other factors, i.e. deism and immanentism. But this assumption totally neglects the fact that many religious texts within both the Jewish and Christian bible and the rest of the Christian tradition refer to God as non-personal or apersonal. In many ways and in many times God is referred to in abstract terms, which is to say nouns like justice, love, and peace, and substantialized participia like the revealing, the hidden, the present, the absent, the coming and so on (McKenzie 1988; Johnson 1995). Here we convincingly mention the aniconic tradition that does not, in fact, use any image of God, let alone an anthropomorph image, and that started as far back as the Jewish bible and has permeated the religious consciousness of all ages since, while at the same time referring to the prohibition to create anthropomorphic images of God, to which we will come back in the next part. The SOCON assumption that God within the Christian faith is a personal God only, also neglects the fact that many theologians express their fundamental concern about, if not objection to, looking at God as a person. For example, Tillich pointed out the danger that naming God 'a person' might lead to understanding God as 'a being' instead of 'being' or 'depth of being', or even worse God as 'an individual being'. This would fundamentally neglect the all-encompassing mystery which God is, which is to say 'His being in everything' and 'everything being in Him', as Paul says in the first letter to the Corinthians 15:28 (Tillich 1966; Dombrowski 1996; Nikkel 1995).

The second reason why we doubted the SOCON instrument's validity has to do with the factor called deism. Why should the items constituting this factor exists be labeled as deistic only and not as Christian also, because the bible contains plenty of passages in which God is seen as non-personal? The wisdom literature is full of it, like Job, Psalms, Proverbs, Ecclesiastes, Wisdom and Sirach. Further, the New Testament uses the so-called passivum divinum', like 'Ask, and it will be given you; search, and you will find; knock, and the door will be opened for you' (Mt 7:7) (cf. Schoonenberg 1986; Schillebeeckx 1989:83). Moreover, the label deism' creates a contrast between personal and non-personal images of God that overlooks the complexity and richness of the mystery of God in itself. A term like 'higher power' surely can refer to the experience of a personal God, whereas a term like 'personal God' may refer to a popular, albeit old-fashioned, image of God being an old man with a beard sitting on the clouds (Van Peursen 1981:152-166).

The third reason why we take a critical stance against the SOCON instrument has to do with an ongoing discussion with regard to the term 'immanentism', the question being: is this immanentism religious or secular only? Everything depends on how one reads and understands the items constituting this factor, namely from a religious or secular perspective. In other words, a Christian might interpret the item 'To me, God 
is nothing but the valuable in a 'human being' or 'God is not up there, but only in the hearts of people' in such a way that he or she (polemically) rejects all kinds of absolute transcendence, which removes God from everything that is valuable in human life. But a non-believer might also interpret the item 'To me, God is nothing but the valuable in a human being' or 'God is not up there, but only in the hearts of people' in such a way that he or she only sees God as a kind of projection, while exclusively reducing God to human's projecting capacity and consciously referring to transcendence as being intrinsically human transcendence only. It is also possible to read in a mutually different way, with the first item (more or less) having a secular meaning only and the second item (more or less) a religious one. The significantly different scores on both items by our population of young people, which we will discuss further on, may be an indication of this. After all, immanentism, being the third factor in the SOCON instrument, is ambivalent in its meaning (see Peters 1996).

The fourth and last reason why we doubted the appropriateness of using the SOCON instrument in our research, is contextual in nature. The two last concepts stemmed, as we said, from the Enlightenment in the eighteenth century and the second wave of the Enlightenment during the cultural revolution between 1965 and 1975 . Asking whether these concepts, deism and immenentism, fit into South African social and religious conditions, really is a rhetorical question, because this country has never been directly influenced by the Enlightenment nor the second wave of this cultural movement. Only very recently, since the 'new' South Africa came into being in 1994, have the political and social institutions been transformed in the direction of a democracy to be developed and human rights to be acted upon, that are the fruits of a process that started in the western world several centuries ago and that will take a long time before they are really incorporated in the minds and hearts of people and their culture ${ }^{12}$.

The reason why we decided to use the SOCON instrument in our research, despite the objections we formulated, is because it is a reliable instrument that frequently showed its robustness. Furthermore it enables us to develop comparisons with other populations that have been investigated with the help of this instrument ${ }^{13}$.

Table 1: Interpretations of God according the SOCON instrument

Traditional Christian belief 
Table 1 shows the averages for the three interpretations of the belief in God we discussed ${ }^{14}$. It is interesting to see that a population of students at Anglican and Catholic secondary schools, who are supposed to take part in the intensely traditional Christian religiosity that characterizes South African society as a whole, show averages regarding traditional Christian belief in God and deistic belief in God that are about identicial, namely 4.0 and 4.1. Both are evaluated in a clearly positive way, albeit that the one refers to a personal God and the other to a nonpersonal God. Immanentism, on the contrary, is evaluated in a rather negative way, as the average (2.9) shows, so that the two items that this measuring scale consists of have to be taken into account separately. The first item ('To me God is nothing but the valuable in a human being') scored negatively (2.5) and the second ('God is not up there, but only in the hearts of people') rather ambivalently, albeit more positively than negatively $(3.2)^{15}$. This difference between both immanentism items may indicate that the first item is in fact understood in a (more or less) secular sense only, and the second in a (more or less) religious sense as we suggested earlier ${ }^{16}$.

\section{A SYSTEMATIC APPROACH: THE NISET INSTRUMENT}

Because of our doubts about the SOCON instrument's conceptual and construct validity, we used a second instrument in order to measure the youth's interpretations of God and their evaluation of them, namely the NISET instrument. This instrument is the (provisional) outcome of a rather long process of item construction, for which both an inductive and a deductive approach were used that together contained four phases. In the first phase answers were gathered to open questions about the meaning of the word 'God' among adolescents and these were then transposed into an item format by the departments of psychology and sociology of religion in Louvain (Verhoeven 1994). In the second phase the inductively established items were complemented with other ones from a theoretical-theological point of view, resulting in a list of 53 both anthropomorphic and nonanthropomorphic items (Van der Ven 1993:218-223). These items were divided into three groups: items referring to God's absolute transcendence, immanent transcendence, and immanence. Within each of these three groups, the items appeared to correlate sufficiently with one another in order to form one or more factors (Van der Ven \& Biemans 1994:84-89). In the third phase we constructed a new list of 24 items from these three groups which referred only to anthropomorphic images of God and this resulted in a number of relevant factors (Report Research Project 1996:22-25). In the fourth and last phase we reduced the number of items, replaced some of the rest of them, then again complemented them with items referring to both anthropomorphic and non-anthropomorphic images of God, and added some items 
referring to divine aniconism, which relates to human's incapability to construct adequate images of God, all of which resulted in a list of 24 items again. We used this last list in our research among South African youth ${ }^{17}$.

Reconstructing this list, we can say that its basic pattern is a theological model covering four different levels ${ }^{18}$. At the first level we distiguish between iconic and aniconic belief in God. Iconic belief in God is based on anthropomorphic and nonanthropomorphic images of God and uses these images as a way of approaching God adequately. Aninconic belief in God, in which the prefix an functions as a socalled alpha privans, rejects these images as a way of knowing God. While aniconism can have different meanings, we determined its focus along factual-epistemological lines. In this article aniconism does not refer to the prohibition on constructing images of God, which is known as the total biblical ban on images, but its underlying rationale is humans' inability to know and completely or at least adequately understand God, which leads humans into the 'cloud of unknowing'. While aniconism transcends all forms of theism, whether plain theism, panentheism or pantheism, it can be referred to in terms of metatheism, in which the prefix 'meta' refers to 'that which comes after all forms of theism mentioned'. The form of transcendence that is implied in this metatheism is not so much metaphysical or ontological in nature, but epistemic: metatheism transcends all forms of knowing and naming God ${ }^{19}$.

At the second level, the iconic belief in God, we distintinguish between anthropomorphic and non-anthropomorphic images of God: God is seen as a personal God or as 'something higher.' We believe we are justified, and even enjoined, in including images of an impersonal God as well as a personal God on the list for we have often been struck in our own empirical research by the fact that people easily mix up personal and impersonal images for God (Van der Ven 1992). From another research project among young people, this one qualitative in design, it appears that most of the subjects apply neither a paternal nor a maternal image to God. Only a few of them refer to a personal God (Janssen et al 1994). In addition, a more general observation that could be made based on a survey of the Dutch population is that the impersonal images seem to be advancing (Goddijn et al 1967, 1979), or at any rate are exhibiting a somewhat less severe drop than personal images (Felling et al 1992:40-41).

At the third level we distinguish between different forms of images of God from the perspective of God's transcendence and immanence, which is to say: God can be interpreted as absolutely transcendent, immanent-transcendent, or immanent. The first aspect, God's absolute transcendence, can be represented in terms of theism, the second, God's immanent transcendence, in those of panentheism, and the third, God's immanence, in those of pantheism. This division into three forms can be called com- 
prehensive in terms of Hartshorne's process theology. It is also exclusive in the logical sense. Theism states that God and the world are completely separated from each other, and that God exists above the world and unrelated to the world in every respect. Pantheism states that God is the structure and wholeness of the world and can in no way exist separately from the world. God exists as the unity of the world. Panentheism completely rejects the pure contradiction that exists between classical theism and pantheism. Both are based on an interpretation of God's simplicity, which is unipolar and rules out any possibility of bipolarity in God: God is either transcendent or immanent. Panentheism does not occupy a kind of in-between position, as if there were three logical positions that can be distinguished in the coordinating sense. It moves beyond both theism and pantheism by emphasizing God's bipolarity 20 . In panentheism, God and the world are seen as referring to each other: God is as much in the world as the world is in God (Hartshorne \& Reese 1953; Tracy 1988; Schoonenberg 1986, 1991).

At the fourth level, this panentheism is divided into four aspects: individual, social, cosmic, and ontological panentheism. The reason is that God's relatedness to the world can actualize in four ways, because 'world' is fourfold: the world of each individual, the social world of people's interrelatedness, the cosmic world of nature, and the ontological world of all of these three categorical worlds together. The division into these four different worlds is in accordance with the classic approach of the question about how to approach God, know Him, or even give evidence of His existence (Ganoczy 1986:209ff; Häring 1991:299).

Working with the various distinctions at these four levels, we formulated a theoretical outline of items related to the different interpretations of God. As the following figure shows, first the interpretations of God are divided into iconic and aniconic ones. Secondly, the iconic interpretations are divided into anthropomorphic and non-anthropomorphic ones, alongside the non-anthropomorphic aniconic interpretations. Thirdly, both the anthropomorphic and non-anthropomorphic interpretations are divided into three ways of understanding God: as absolute transcendent, immanent transcendent, and immanent. These are represented by theism, panentheism and pantheism respectively. At this level, the aniconic, non-anthropomorphic interpretations of God refer to what we called epistemic transcendence. Fourthly, panentheism is divided into four forms: individual, social, cosmic, and ontological panentheism. At this level we localized metatheism, while subsuming it under the aniconic, non-anthropomorphic interpretations. Lastly we made two restrictions, one regarding pantheism and one regarding aniconism. The first restriction was to drop the pantheistic interpretations from the list of the anthropomorphic images and reserve them exclusively for the non- 
anthropomorphic ones, because the images in which God is presented as personal and thus as transcendent do not fit in with the immanence of pantheism (Schoonenberg 1986). The second restriction was this: we exclusively reserved the concept 'of aniconism to the non-anthropomorphic images because it refers to not using anthropomorphic images ('God, our father') alongside theriomorphic images ('God is an eagle') or physiomorphic images ('God is my rock') to represent God. We then started the process of operationalizing these concepts, that is we made each concept operational with the aid of two items, which amounts to $(5 \times 2=) 10$ anthropomorphic items plus $(7 \times 2=) 14$ non-anthropomorphic items, resulting in 24 anthropomorphic and nonanthropomorphic items.

\section{Figure: Interpretations of God}

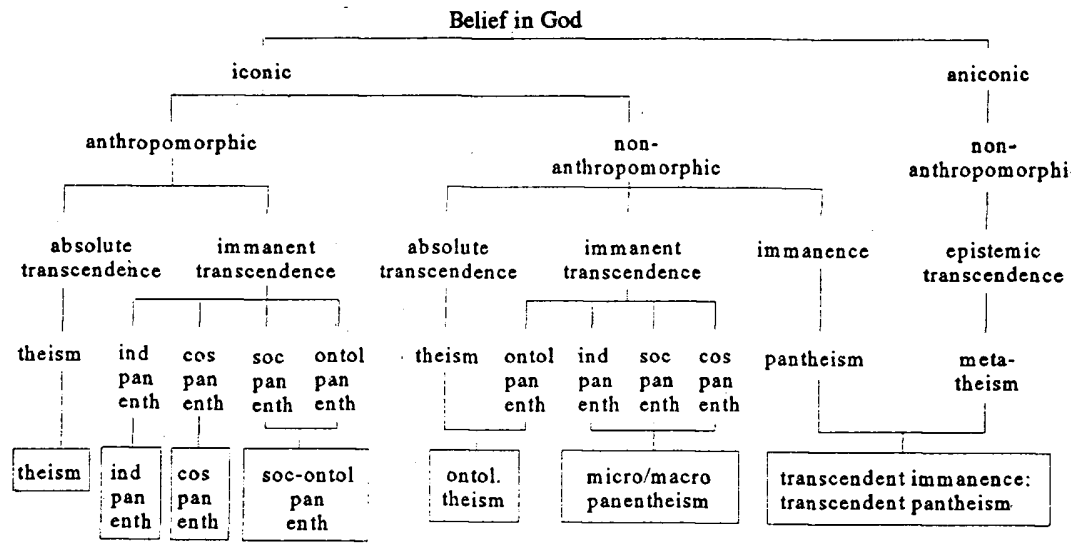

Abbreviations: indpanenth $=$ individual panentheism, cospanenth $=$ cosmic panentheism, socpanenth, social panentheism, ontolpanenth $=$ ontological panentheism, soc-ontolpanenth $=$ social-ontological panentheism, ontol. theism $=$ ontological theism

Now we were able to specify the first specific question we asked at the end of the first part of thisarticle, namely what interpretations of God exist among South African youth? This question can be formulated in a more specific way: do the interpretations of God that exist among South African youth reveal the same structure as the above figure suggests? This question can be divided into the following subquestions. 
* Are their interpretations of God divided into iconic and aniconic ones?

* Are their iconic interpretations divided into anthropomorphic and non-anthropomorphic ones?

* Are their anthropomorphic images divided into two different groups, referring to God's absolute and immanent transcendence?

* Are the anthropomorphic images that relate to God's immanent transcendence divided into four different groups, that is individual, social, cosmic and ontological immanent transcendence? And with regard to the non-anthropomorphic images, the following questions may be asked:

* Are the non-anthropomorphic images divided into three different groups, referring to God's absolute, immanent transcendence, and immanence?

* Are the images that relate to God's immanent transcendence divided into four different groups, that is individual, social, cosmic and ontological immanent transcendence?

In order to be able to answer these questions, we conducted an overall factor analysis on the responses given by about 350 students from standard 9 who then were attending Anglican and Catholic private schools in the Johannesburg/Pretoria region, as we said at the end of part 1 of this article, and in fact responded to the list of 24 items $^{21}$. While three items had to be elimated for statistical reasons ${ }^{22}$, the factors that could be extracted from the students' responses to the rest of the items, appeared to be seven in number as the above figure shows: four factors among the anthropomorphic interpretations and three factors among the non-anthropomorphic ones ${ }^{23}$.

The four factors among the anthropomorphic interpretations are: 1) theism (absolute transcendence), 2) individual panentheism (individual immanent transcendence), 3) cosmic panentheism (cosmic immanent transcendence), and 4) socialontological panentheism (social-ontogical immanent transcendence). This last factor is interesting, because it plays a different role from what we expected. It gives an Qntological foundation to the social, intersubjective image of God: human's togetherness appears to be ontologically based in God. In other words, the love and solidarity between men and women are ontologically rooted in God, and - in reverse - God is revealed as the ontological basis of humans' mutual belonging and engagement. 
The three factors among the non-anthropomorphic interpretations are: 5) ontological theism (absolute transcendence combined with ontological immanent transcendence), 6) micro/macrocosmic panentheism (individual, social, cosmic immanent transcendence), and 7) transcendent pantheism (transcendent immanence).

To begin with factor 5 , ontological theism (absolute transcendence combined with ontological immanent transcendence), it is interesting to see that the ontological way of knowing God again plays a role that is different from what we expected it to be. As we saw among the anthropomorphic interpretations, it combines with another form of immanent transcendence (social and ontological panentheism), but among the nonanthropomorphic interpretations, it couples with absolute transcendence (theism and ontological panentheism). In other words, the ontological approach to God shows an ambivalent characteristic, because it relates to both immanent transcendence - among the anthropomorphic images - and absolute transcendence - among the non-anthropomorphic images. We may say that it is anthropomorphically close, while nonanthropomorphically distant and remote.

Factor 6, micro/macropanentheism, does not behave in the way we expected either. Combining individual, social and cosmic panentheism, we call this factor micro/macrocosmic panentheism, because individual and social panentheism refer to the microcosmos of human existence, whereas cosmic panentheism relates to the macrocosmos of all living and non-living nature.

Lastly, factor 7, transcendent pantheism, which combines pantheism and metatheism, deserves our attention for two reasons, because it is not only relevant from the perspective of metatheism, but also from that of pantheism. First, we expected this metatheism to be absolutely separate from all other concepts, because, as we said, it transcends all forms of theism, whether plain theism, panentheism or pantheism. Amazingly, because this metatheism forms one factor with pantheism, this disregards and even repudiates our previous fundamental distinction between iconic and aniconic interpretations of God. Pantheism is, so to say, not iconic only, but both iconic and aniconic in nature. With this we come to the second reason why factor 7 is interesting, because it gives pantheism a specific perspective. Frequently pantheism is described as representing God's absolute immanence, and not God's immanence as such without any further qualification, as we interpreted it, because it states that God exhaustively coincides with all of the world in every respect. From this point of view, there is no difference between God and the world, because they equal one another, the one existing exclusively of the other and vice versa. In other words, pantheism, referring to God's absolute immanence, lacks any kind of transcendence whatsoever. For this reason pantheism has been frequently rejected by the church and church-bound philosophers 
and theologians and still is. In theological handbooks it is frequently described in a more or less polemic manner in order to be evaluated in a negative way and rejected as a heresy (e.g. Kasper 1982:38-39; Van Beeck 1994:42-49). However, from factor 7 we interpret pantheism in a different way. Because pantheism combines with aniconic metatheism, it receives a flow of transcendence, at least epistemic transcendence, from it. In sum, God's being the structure and wholeness of the world - which is what pantheism says of God - transcends all our common forms of knowledge and understanding - which is what metatheism says of God. God's being the unity of the world surpasses all our categories and concepts and leaves us with awe and wondering: this is what factor 7 tells us. Here, pantheism is not plain pantheism that represents absoiute immanence, but some kind of transcendence-oriented pantheism that represents transcendent immanence ${ }^{24}$.

Now we are able to answer the specific questions we asked:

* Are our youth's interpretations of God divided into iconic and aniconic ones? No, they are not, because pantheism, which we subsumed under the heading of iconic interpretations, and metatheism, which we subsumed under that of aniconic interpretations, appear to form one factor. This means that our population combines iconic and aniconic ways of approaching God, which is in accordance with what was earlier called de facto aniconism, which is tolerant of icons, as we said, and from the perspective of which iconism and aniconism can be combined.

* Are their iconic interpretations divided into anthropomorphic and nonanthropomorphic ones? Yes, they are, which is astonishing, because in some other research projects we found combinations of anthropomorphic and non-anthropomorphic interpretations, which we understood in terms of complementarity 25 .

* Are their anthropomorphic images divided into two different groups, referring to God's absolute and immanent transcendence? Yes, they are. God's remoteness and distance in anthropomorph theism and His proximity and engagement in anthropomorph panentheism are clearly two different ways of understanding God.

* Are the anthropomorphic images that relate to God's immanent transcendence divided into four different groups, that is individual, social, cosmic and ontological immanent transcendence? Partly they are, partly they are not. Individual and cosmic panentheism appear to be different factors, whereas social and ontological panentheism form one factor, which refers to the ontological basis of human relatedness and love in God, as we have said. 
* Are the non-anthropomorphic images divided into three different groups, referring to God's absolute transcendence, immanent transcendence, and immanence? And f) Are the images that relate to God's immanent transcendence divided into four different groups, that is individual, social, cosmic and ontological immanent transcendence? Again the answer is: partly they are, partly they are not. In the combination of theism and ontological panentheism, God's absolute and immanent transcendence go together, which we labeled ontological theism. But, the other three forms of immanent transcendence, that is individual, social, and cosmic panentheism, together result in one factor, which we called micro/macrocosmic panentheism. Lastly, pantheism that we described as referring to God's immanence, appeared to combine with metatheism, which resulted in a new insight into both pantheism and metatheism. This new understanding led us to construct a new term: transcendent immanence 26 .

Lastly we investigate the youth's evaluation of the interpretations of the belief in God which we found. In table 2 we see the average scores on the anthropomorphic and non-anthropomophic images. It is interesting to see that the highest average scores are given to three forms of anthropomorph panentheism, that is individual panentheism (4.4), cosmic panentheism (4.3) and social-ontological panentheism (4.3). Then two forms of non-anthropomorph interpretations follow, that is ontological theism (4.1) and micro/macro panentheism (4.0). The lowest scores are given to non-anthropomorph transceNdent pantheism (3.6) and anthropomorph theism (3.5). Althought these last scores are the lowest, they still imply a positive evaluation overall 27 .

Table 2: Belief in God according to the NISET instrument

anthropomorph

theism

individual panentheism

cosmic panentheism

social-ontological panentheism non-anthropomorph

3.5 ontological theism

4.1

$4.4 \mathrm{micro} / \mathrm{macro}$ panentheism

4.0

4.3 transcendent pantheism

3.6

Given our discussion of immanentism within the SOCON instrument, the score regarding transcendent pantheism obtained using the NISET instrument is interesting. As 
table 1 shows, immanentism is rather negatively evaluated (2.9), whereas transcendent pantheism, which we interpreted in terms of transcendent immanence, is clearly positively evaluated (3.6), as table 2 shows ${ }^{27}$.

We would like to stress the point which is emerging from the last table, namely that our students do not hold one interpretation or image of God only, but several of them. Frequently, theological discussions deal with the question of whether this image or that image of God is relevant, meaningful, tolerable, or even legitimate, while rigidly posing this question in mutually excluding 'either/or'-terms. Our students do not suffer from that kind of closed-mindedness, because they clearly favour all seven approaches to believing in God, although they do cherish some of them, for example anthropomorph panentheism, more than others, for example anthropomorph theism. While bearing all seven interpretations in a more or less equally positive manner in mind, they cherish a pluriformity of images of God. In this they are like Goethe's Faust, who evidently appears to believe in God in three really different ways: as a pantheist while doing research in the natural sciences, a polytheist while working as an artist and poet, and a monotheist while reflecting on religion's ethical function for society (Pelikan 1995). We may have a rather similar case with our students, as their interpretations of God might emerge from their interaction with different situations they find themselves in. Let us formulate some suggestions that deserve further empirical exploration and investigation: is it not understandable that our students would cherish a kind of anthropomorph theism, when they find themselves in nature, walking along a long chain of huge rocks that have been there for hundreds of millions of years and are impressed by them, while feeling that a divine creation must have been at the beginning of all of this, independently of any human desire, will or action? Or that they cherish a kind of anthropomorph individual panentheism, while being aware of God's dwelling in their innermost self, like Augustine who said that God was closer to him than he was to himself? Or that they cherish a kind of anthropomorph cosmic panentheism, while thanking God in their inarticulate prayer for the veld's beauty they feel touched by? Or that they cherish a kind of social-ontological panentheism, when they feel that God is actively present in their love life because of the utmost contigently surprising gift the significant other is to them? Or that they cherish a kind of non-anthropomorph ontological theism, while listening to the abstract late string quartets by Beethoven, while esthetically reflecting on the divine design and the compositions' transcendence that overwhelm them. Or that they cherish a kind of non-anthropomorph micro/macro panentheism, when their feelings of awe and wondering are evoked by experiencing the divine gift of specialness, unity, and wholeness in humans and nature all together? Or that they cherish a kind of transcendent pantheism, while practicing the Zen art of 
objectless meditation, while going beyond any idea or conception in the direction of the cloud of the unkown? In other words, does the divine mystery of transcendence not have various aspects that can be approached from various images, have various names and stem from various situations? We should not be misunderstood: we do not have the answers to all these questions, but merely suggest them to make them an object for fur ther theory development and research 29 .

\section{CONCLUSION}

From the above we are not able to answer the question whether South Africa's belief in God is declining, because we have no two or more datasets at our disposal that stem from two or more different points in time. But as far as youth in general and South African youth in particular can be seen as the main bearers of societal and cultural and more specifically religious developments to come, the answer we may formulate from the data we found is: the level of belief in God among South African students from Anglican and Catholic schools in the Johannesburg/Pretoria region, is high to very high. The lowest score finds itself within the positive domain of evaluation (transcendent pantheism: 3.6), whereas the highest scores find themselves in the very positive domain (individual, cosmic and social-ontological panentheism: 4.4, 4.3, 4.3). But the question is whether on the depth level other processes are at work, that on the surface level are hidden from view, which we investigate in the next article.

\section{End Notes}

1 Promotion of National Unity and Reconciliation Act, passed by the Parliament and signed by the President in July 1995, Introduction.

2 For the intrinsic connection between truth and reconciliation within Desmond Tutu's speeches and sermons during the apartheid system, see Van der Ven (1996). Beyers Naudé also frequently argued for truth and reconciliation (see Naudé 1995:147-151). About the meaning and relevance of Beyers Naudé, see Berkhof et al (1985).

3 This sample shows the following demographic characteristics: 49\% are boys, $51 \%$ girls; $67 \%$ of them have English and $33 \%$ one of the ten other official languages as their home language; the highest education level of $26 \%$ of their fathers and $34 \%$ of their mothers falls in the category standard 1 through 10 , that of $48 \%$ of their fathers and $54 \%$ of their mother in the category one form of continuous education after standard 10 or another, whereas $27 \%$ of their fathers and $12 \%$ of their mothers have a master's of doctoral degree; 34\% support the ANC, 25\% the Democratic Party, 29\% the National Party, whereas 12\% support other parties; $31 \%$ of them are Catholic, 26\% Anglican, $8 \%$ Methodist, $23 \%$ belong to another Christian community, $8 \%$ to another religion, whereas $4 \%$ say they do not belong to any religion. 
4 Even the expressions of small children who are not yet able to speak, can be said to be cognitively structured, in so far as they interact with caregivers like parents and siblings who exchange all kinds of messages with these children, which are mediated by cognitively structured linguistic utterances and patterns, as this is shown in Garrod 'Approaches to Moral Development' (1993). For the stage of formal operations see Piaget \& Inhelder 'La psychologie de l'enfant (1964),

5 Validity refers to whether the measuring instrument measures what it is supposed to measure, while construct validity relates to one specific concept and conceptual validity to the broader conceptual network. Reliability refers to whether the instrument measures what it is supposed to measure in exactly the same way each time (De Groot 1964).

6 This interpretation goes beyond the SOCON documents in fact, which is not to say that it contradicts these documents, because in some instances they refer to the contrasting 'pair traditional/modern', as can be seen in Felling, Peters \& Schreuder (1986 and 1987).

7 In accordance with what is said in the previous note, 'traditional' here contrasts with 'modern', which is not to say that no other terms are used, like restauration versus revolution (Felling, Peters \& Schreuder 1986:32-33).

8 The cultural revolution took place in the sixties and seventies of this century, especially between 1965 and 1975 (see Peters 1993). This cultural revolution, which appeared to be a revolution of consciousness especially within social and cultural institutions, like marriage, family, school and university, religion and church, also influenced the definition of immanentism by the SOCON researchers from the verticalism/horizontalism concept that played a key role in those days (see Van der Ven 1968). Today still the verticalism/horizontalism relation (co)determines the parameters of the religious discours (see Häring 1991).

9 In a research project conducted among students of Nijmegen University, the only item out of $\mathbf{5 3}$ items (!) that was positively evaluated on average, reads as follows: "There is a power that transcends the merely visible" (see Van der Ven \& Biemans 1994:85).

10 For philosophers and theologians who reject deism, see for example: De Boer (1991), Vroom (1992). Social scientists also refer to the abstraction process and the resulting vagueness of God within deism, see for example: Laeyendecker (1992). We cannot go into detail here regarding civil religion in the apartheid system (see Oosthuizen 1985:38-40 about 'Afrikaner civil religion' or: De Cruchy \&Villa-Vicencio 1983) nor can we deal here with the relation between the apartheid system and the Nazi state (see Naudé 1995:86).

11 Clear evidence for that can be found in the poems and liturgical prayers by the Dutch poet Huub Oosterhuis in his 'Gebeden en psalmen' (1984) and 'Van U is de toekomst - Kome wat komt' (1996).

12 Dirkie Smit (1996:193): 'met die oorgang na 'n pluralistiese, sekulêre, demokratiese samelewing, na 'n grondwetlike bestel, gebaseer op 'n katalogus van menseregte en beskerm deur 'n 
konstitutionele hof in 'n regstaat, na 'n markekonomie met gepaardgaande vryhede vir die individu; na 'n burgerlike samelewing (civil society) met talryke outonome openbare instellings, organisasies en inisiatiewe; en na 'n ongekende proses van openbare meningsvorming, institusionaliseer die Suid-Afrikaanse samelewing feitlik oornag prosesse wat in Westerse lande eeue geneem het om hulle te voltrek'.

13 This reason made us disregard the totally unexpected outcome of the factor analysis we conducted, which resulted in two factors only, namely traditional Christan belief and deism. The two items referring to immanentism had to be eliminated because of statistical reasons, their correlation (r.17) being too low for a factor to be extracted. This outcome is totally unexpected, because immanentism always shows up as a separate factor in any factor analysis conducted. On some occasions to date, the SOCON instrument has resulted into two factors only, with the items referring to the traditional Christian belief and those of deism appearing to form one factor, alongside the immanentism factor, as was the case in the research among the Dutch population in 1985 or parts of it (see Pieterse, Scheepers \& Van der Ven 1993). On no occasion so far has immanentism disappeared as a factor, which suggests that our population of South African youngsters may be seen as functioning as a kind of counter-example. We come back to this in part 3 .

${ }^{14}$ All scales in the tables of this article run from 1.0 (very negative) to 5.0 (very positive).

15 We interpret scores 1.00 through 1.79 as very negative, 1.80 through 2.59 as negative, 2.60 through 3.39 as half-negative/half-positive, 3.40 through 4.19 as positive, and $4.20-5.00$ as very positive.

16 This is not the first time that the SOCON instrument has been used in South Africa. In one of our previous articles we measured belief in God among parishioners in Pretoria with the help of the same items (cf. Pieterse et al 1993). In that article, traditional Christian belief was called personal theism, deism was called apersonal theism, and immanentism was called pantheism. The average for personal and apersonal theism together was 23.3 on a scale that runs from 5 to 25 , whereas the average for pantheism was 5.1 on a scale that runs from 2 to 10.

17 This list of 24 items was presented to a random sample of 1646 people from the Duth population in the context of the fourth wave in 1995 as part of the SOCON panel research.

18 Here the description of the theological model and its four levels differs conceptually from its description in Van der Ven (1997; especially 158-160), where we spoke of two dimensions only.

19 For the distinction between programmatic aniconism or de iure aniconism and de facto aniconism in the biblical traditions, see Schmidt (1995) in which the consensus about programmatic aniconism in the biblical traditions is challenged, because they are characterized by de facto aniconism, which is conventional, tolerant, or indifferent to icons. Aniconism can also be found in what is called metatheism (see Krüger 1989). For the distinction between metaphysical and epistemic transcendence see Levine (1994:93ff). 
20 The statement 'Thus there are logically three views' (Hartshorne 1976:90) gives the impression that there are three logical coordinating positions. Elsewhere Hartshorne (in particular in Hartshorne 1948-1949) emphasizes the transcending character of panentheism.

21 As we said before, the original sample contained 538 students, but because of technical reasons only about 350 students responded to the list of 24 items about the belief in God.

22 For the statistical conventions used for the factor analyses in this article, see Van der Ven (1993).

23 The factor analysis output used in this article is available from the authors.

24 This interpretation of factor 7 is in accordance with the research on pantheism by the Australian theologian Paul Levine in his Pantheism: A Non-theistic Concept of Deity' (1994).

25 In the research among Nijmegen students we found this complementarity (see Van der Ven \& Biemans 1994: 87-88).

26 From this, we distinguish four, at least theoretical, dimensions from which God's being can be approached: absolute transcendence, immanent transcendence, transcendence immanence and absolute immanence. In a pilot study in 1996 on the belief in God among 82 students of a secondary school in 's Hertogenbosch in the Netherlands, who were 16 to 17 years of age, we were able to draw four factors from their responses to a new list of images of God that refer to the four dimensions mentioned.

27 Cf. note 15 .

28 The correlation coefficient between immanentism and transcendent immanentism (transcendent pantheism) is $r .23$, which is to be evaluated as rather low.

29 All these questions refer to what may be called a situational approach to the divine names (' $\mathrm{De}$ nominibus Dei'), as other approaches might also appear to be worthwhile, like a personalityoriented, cultural, structural or institutional approach.

\section{Works Consulted}

Berkhof, $\mathrm{H}$ et al 1985. Met de moed der hoop. Opstellen aangeboden aan Dr. C.F. Beyers Naudé, met een bijdrage van C.F. Beyers Naudé. Baarn: Ten Have.

Beyer, P 1994. Religion and Globalization. London.

De Boer, Th 1991. De God van de filosofen en de God van Pascal. Den Haag.

De Cruchy, J \& Villa-Vicencio, C (eds) 1983. Apartheid is a Heresy. Cape Town: David Philip.

De Groot, A D 1964. Methodologie. Den Haag. 
Dombrowski, D.A 1996. Analytic Theism, Hartshorne, and the Concept of God. New York.

Doorenbos, J et al 1987. Modernisering in West-Europa. Een tweedeling?, in Halman, L, Traditie, secularisatie en individualisering, 234ff. Tilburg: Tilburg University Press.

Ester, P, Halman, L \& De Moor, R 1993. The Individualizing Society. Tilburg: Tilburg University Press.

Felling, A, Peters, J \& Scheepers, P 1992. Individual Changes in the Netherlands 1985-1990. Steinmetz Archive, Amsterdam.

Felling, A, Peters, J \& Schreuder, O 1986. Geloven en leven. Zeist.

- 1987. Religion im Vergleich. Frankfurt.

Ganoczy, A 1986. Dieu, grace pour le monde: Le christianisme et la foi chrétienne. Paris. (Manuel de théologie 8.)

Garrod, A 1993. Approaches to Moral Development. New York.

Gay, P 1966. The Enlightenment. New York.

1968. Deism. Princeton.

Greeley, A M 1995. Religion as Poetry. New Brunswick/London: Transaction.

Goddijn, W et al 1967. God in Nederland. Amsterdam.

Goddijn, W et al 1979. Opnieuw: God in Nederland. Amsterdam.

Halman, L et al 1987. Traditie, secularisatie en individualisering. Een studie naar de waarden van de Nederlanders in een Europese context. Tilburg.

Häring, H 1991. Eerlijk voor God? Over de resultaten van een voortgaande discussie. Tijdschrift voor Theologie 31, 218-315.

Hartshorne, C 1948-1949. Das Metaphysische System Whiteheads. Zeitschrift für Philosophische Forschung 3 (1948-1949), 566-575.

1976. The Divine Reality: A Social Conception of God. New Haven/London.

Hartshorne, C \& Reese, W (eds) 1953. Philosophers speak of God. Chicago.

Janssen, $\mathrm{J}$ et al 1994. Images of God in Adolescence. The International Journal for the Psychology of Religion 4, 2, 105-122.

Johnson, E A 1995. She Who Is: The Mystery of God in Feminist Theological Discourse. New York.

Kasper, W 1982. Der Gott Jesu Christi. Mainz.

Krüger, J S 1989. Metatheism. Pretoria.

Laeyendecker, L 1992. Het vervagend Godsbeeld. Enkele sociologische opmerkingen, in Arts, W A et al (ed), Tempora mutantur, 28-50. Baarn.

Levine, P 1994. Pantheism: A Non-theistic Concept of Deity. London/New York.

Mandela, N 1995. Long Walk to Freedom. London: Abacus. 
McKenzie, P 1988. The Christians, Their Belief and Practices. Nashville.

Naudé, C F B 1995. My land van hoop. Die lewe van Beyers Naudé. Kaapstad: Human \& Rousseau.

Nikkel, D H 1995. Panentheism in Hartshorne and Tillich, A Creative Synthesis. Frankfurt.

Oosterhuis, H 1984. Gebeden en psalmen. Baarn.

- 1996. Van $U$ is de toekomst - Kome wat komt. Leuven/Kampen.

Pelikan, J 1995. Faust the Theologian. New Haven/London.

Peters, J 1993. Individualisering en secularisering in Nederland in de jaren tachtig.

KU Nijmegen. Nijmegen.

Peters, J 1996. Nederlandse katholieken tussen christelijke en binnenwereldlijke levensbeschouwing, in Peters, $\mathrm{J}$ et al, Geloven in deze tijd, Onderzoek en perspectief, 5-49. KASKI-reeks, Ubbergen.

Piaget, J \& Inhelder, B 1964. La psychologie de l'enfant. Paris.

Pieterse, H J C, Scheepers, P L H \& Van der Ven, J A 1993. Plural Religious Beliefs. HTS 49, 1/2, 189-220.

Population Census 1991. Summarized Results after adjustment for undercount. No. 03-01-01. Central Statistical Service, Pretoria.

Report Research Project 1996. Ouders en de identiteit van katholieke basisscholen. NISET, Nijmegen:

Schillebeeckx, E 1964. Openbaring en theologie. Bilthoven.

1989. Mensen als verhaal van God. Baarn.

Schmidt, B B 1995. The Aniconic Tradition, On reading Images and Viewing Text, in Edelman, D V (ed), The Triumph of Elohim, From Jahwismus to Judaismus, 75105. Kampen:Kok Pharos.

Schoonenberg, P 1986. Auf Gott hin denken. Freiburg.

- 1991. De Geest, het Woord en de Zoon. Theologische overdenkingen over Geest-Christologie, Logos-christologie en Drieëenheidsleer. Kampen: Kok.

Smit, D 1996. Oor die unieke openbare rol van die kerk. Tydskrif vir Geesteswetenskappe 36, 3, 190-204.

Sociaal-Culturele Ontwikkelingen in Nederland 1995. Schalenboek. Nijmegen.

Tillich, P 1966. Systematic Theology. Volume I. Chicago.

Tracy, D 1988. Blessed Rage for Order. The New Pluralism in Theology. San Francisco.

Van Beeck, F J 1994. God Encountered: A Contemporary Catholic Systematic Theology. Collegeville.

Van der Ven, J A 1968. Horizontaal en verticaal in Schleiermachers dogmatiek. Vox theologica, 181-199. 
Van der Ven 1992. God in Nijmegen: Een theologisch perspectief. Tijdschrift voor Theologie 32, 3, 225-249.

1993. Practical Theology, An Empirical Approach. Kampen: Kok.

1996. The Religious and Moral Self as a Process, in Pieterse, H J C, Desmond

Tutu's Message, 74-95. Kampen/Weinheim: Kok/Deutsche Studienverlag. (Serie Theologie \& Empirie 24.)

Van der Ven, J A \& Biemans, B 1994. Religie in fragmenten. Kampen: Kok.

Van der Ven, J A, Dreyer, J S \& Pieterse, H J 1997. Religious Consciousness in a Transformative Perspective. The International Journal of Practical Theology (1997) 1, 110-135.

Van Peursen, C A 1981. Toekomst van kerk en godsdienst in Nederland. Goddijn, W (ed). Hebben de kerken nog toekomst? Commentaar op het onderzoek 'Opnieuw: God in Nederland', 152-166. Baarn. (Annalen van het Thijmgenootschap 69,1.)

Verhoeven, D 1994. De levensbeschouwing van studenten aan de K.U. Leuven. Een sociaal-wetenschappelijke studie, K.U. Leuven, Departement sociologie SSD/36. Leuven.

Vroom, H (ed) 1992. De God van de filosofen en de God van de bijbel. Zoetermeer. 